\title{
Pengaruh Masase pada Punggung Terhadap Intensitas Nyeri Kala I Fase Laten Persalinan Normal Melalui Peningkatan Kadar Endorfin
}

\author{
Yeni Aryani ${ }^{1}$, Masrul ${ }^{2}$, Lisma Evareny ${ }^{3}$
}

\begin{abstract}
Abstrak
Nyeri saat persalinan merupakan proses yang fisiologis. Sebanyak $12 \%-67 \%$ wanita merasa khawatir dengan nyeri yang akan dialami saat persalinan. Salah satu upaya untuk mengurangi nyeri persalinan adalah dengan masase. Tujuan Penelitian ini untuk mengetahui pengaruh masase pada punggung terhadap intensitas nyeri kala I fase laten persalinan normal melaui peningkatan kadar endorfin. Ini merupakan suatu penelitian experimental dengan post test only control group design yang dibagi atas kelompok perlakuan yang melakukan masase pada punggung dan kelompok kontrol yang tidak masase. Intensitas nyeri dinilai dengan kuisioner dan kadar endorfin diukur dengan human beta endorfin Elisa Kit. Data dianalisis menggunakan uji t-test independent dan korelasi Spearmen. Hasil penelitian ini ditemukan ibu bersalin yang dimasase memiliki intensitas nyeri lebih rendah 29.62 point dari pada yang tidak dimasase nilai $p=0.001$, ada pengaruh masase terhadap intensitas nyeri kala I persalinan normal. Ibu bersalin yang dimasase memiliki endorfin lebih tinggi dari pada yang tidak dimasase sebesar $142.82 \mathrm{pcg} / \mathrm{mlnilai} p=0.001$ ada pengaruh masase terhadap kadar endorfin ibu bersalin normal. Ada korelasi kadar endorfin dengan penurunan intensitas nyeri dengan nilai $r=0,795$ dan nilai $p=0.001$. Kesimpulan penelitian ini adalah masase pada punggung berpengaruh terhadap intensitas nyeri dan kadar endorfin ibu bersalin kala I fase laten persalinan normal serta kadar endorfin berkorelasi dengan intensitas nyeri kala I fase laten persalinan normal.
\end{abstract}

Kata kunci: masase pada punggung, intensitas nyeri, kadar endorfin.

\section{Abstract}

Pain in delivery is a physiological process. About $12 \%-67 \%$ of women feel the pain during delivery. One of the ways to reduce pain during delivery process is to massage mother's back. The objective of this research was to determine the effect of massage on the back to the pain intensity in normal delivery based on the level of endorphin. This study was an experimental study with post test only control group design by massaging mother's back in normal delivery process of primiparous phase I for 30 minutes. Data collection was done for three months. The subject were choosen randomly block with 52 respondents. Data processing was done based on the Independent t-test and Spearmen Correlation. The results of this study shows that mothers who have massage on the back before delivery process, feel lower pain intensity in 29.62 points than those who do not have massage. The result of statistical test was $p=0.001$, so, the massage reduces the pain intensity. Mothers who have massage, get their endorphin increased as much as $142.82 \mathrm{PCG} / \mathrm{ml}$ compared to mothers who did not have massage. There was a correlation between the increase of endorphin level with the reduction of pain intensity. The result of statistical test shows that there is a strong correlation between the endorphin level with pain intensity with a value, $r=0.795 a n d p=0.001$. It can be conluded that massage on the back can reduce pain intensity in normal delivery and increase the leve lof endorphin. Furthemore, there is a strong correlation between the increase of endorphin level with pain intensity in normal delivery. It is recommended that massage on the back can be done regularly in every normal delivery. Keywords: massage on the back, pain intensity, level of endorphin 
Affiliasi penulis : 1. Program Studi Magister Kebidanan FK UNAND (Fakultas Kedokteran Universitas Andalas Padang), 2. Bagian IImu Gizi FK UNAND, 3.Poltekkes Kemenkes Padang

Korespondensi:Yeni Aryani, E-mail : yeniaryanigrek@yahoo.co.id, Telp: 081364306800

\section{PENDAHULUAN}

Proses kelahiran identik dengan rasa nyeri yang akan dijalani, dimana sebagian besar persalinan disertai rasa nyeri. Nyeri pada persalinan merupakan proses yang fisiologis. Nyeri menyebabkan frustasi dan putus asa, sehingga beberapa ibu merasa khawatir tidak akan mampu melewati proses persalinan. Sebuah studi terbaru menemukan bahwa $67 \%$ wanita merasa sedikit khawatir, 12\% merasa sangat khawatir dan $23 \%$ sama sekali tidak khawatir tentang nyeri persalinan. ${ }^{1,2}$

Rasa nyeri pada persalinan kala I disebabkan oleh munculnya kontraksi otot-otot uterus, hipoksia dari otot-otot yang mengalami kontraksi, peregangan serviks, iskemia korpus uteri, dan peregangan segmen bawah rahim. Reseptor nyeri ditransmisikan melalui segmen saraf spinalis T11-12 dan saraf - saraf asesori torakal bawah serta saraf simpatik lumbal atas. Sistem ini berjalan mulai dari perifer melalui medullla spinalis, batang otak, thalamus dan kortek serebri. $^{1,3}$

Menghilangkan rasa nyeri ialah hal yang penting. Bukan jumlah nyeri yang dialami wanita yang perlu dipertimbangkan, akan tetapi upaya tetang bagaimana cara mengatasi nyeri tersebut. Hal ini sejalan dengan program yang dicanangkan oleh Kementrian Kesehatan (Kemenkes) yaitu program Making Pregnancy Saver (MPS) dengan salah satu aspek penatalaksanaan dalam persalinan yaitu aspek sayang ibu. ${ }^{4,5}$

Bidan dalam prakteknya memberikan asuhan persalinan diharapkan dapat memberikan kenyamananselama persalinan, untuk itu perlu dilakukan upaya pengendalian nyeri saat persalinan dengan teknik non farmakologis, salah satu diantaranya yaitu masase.Masase dapat meningkatkan relaksasi tubuh dan mengurangi stres. Disamping itu masase merupakan asuhan yang efektif, aman sederhana dan tidak menimbulkan efek yang merugikan baik pada ibu maupun janin. ${ }^{6-8}$

Masase pada punggung merangsang titik tertentu di sepanjang meridian medulla spinalis yang ditransmisikan melalui serabut saraf besar ke formatio retikularis, thalamus dan sistem limbic tubuh akan melepaskan endorfin. Endorfin merupakan neurotransmitter atau neuromodulator yang menghambat pengiriman rangsang nyeri dengan menempel kebagian reseptor opiat pada saraf dan sumsum tulang belakang sehingga dapat memblok pesan nyeri ke pusat yang lebih tinggi dan dapat menurunkan sensasi nyeri. ${ }^{1,9-11}$

Masase pada punggung saat persalinan dapat berfungsi sebagai analgesik epidural yang dapat mengurangi nyeri dan stres, serta dapat memberikan kenyaman pada ibu bersalin. Oleh karena itu diperlukan asuhan essensial pada ibu saat persalinan untuk mengurangi nyeri dan stres akibat persalinan yang dapat meningkatkan asuhan kebidanan pada ibu bersalin. ${ }^{3,12-14}$

Tujuan penelitian ini adalah untuk mengetahui pengaruh masase pada punggung terhadap intensitas nyeri kala I fase laten persalinan normal melalui peningkatan kadar endorfin.

\section{METODE}

Penelitian ini merupakan penelitian eksperimental dengan menggunakan post test only control group design untuk mengetahui pengaruh perlakuan pada kelompok intervensi dengan cara membandingkan dengan kelompok kontrol. Tempat penelitian adalah di ruang bersalin RS Tk III Reksodiwiryo Padang dan laboratorium Biomedik Fakultas Kedokteran Universitas Andalas Padang. Waktu penelitian tiga bulan.

Populasi pada penelitian ini adalah seluruh ibu bersalin primipara kala I fase laten persalinan normal yang berada di RS Tk.III Dr.Reksodiwiryo Padang. Subyek penelitian yang dipilih adalah semua populasi yang memenuhi kriteria inklusi dan eksklusi.Kriteria inklusi dalam penelitian ini adalah ibu bersalin normal yang memenuhi syarat untuk persalinan pervaginam dan bersedia menjadi subjek penelitian.Kriteria eksklusi adalah ibu bersalin normal dengan komplikasi.

Jumlah subjek dihitung dengan menggunakan rumus uji hipotesis terhadap rerata dua populasi independen. ${ }^{16,17}$ Simpang baku kedua kelompok adalah 2.4. Berdasarkan rumus tersebut, 
diperoleh jumlah sampel sebesar 46 orang, ditambah antisipasi drop out $10 \%$ menjadi 52 orang.

$n_{1}=n_{2}=2\left\{\frac{(Z \alpha+Z \beta)}{\left(X_{1}-X_{2}\right)} S\right\}$

Keterangan :

$\mathrm{n}$ = jumlah sampel untuk kelompok perlakuan dan kontrol

$\mathrm{x}_{1}-\mathrm{x}_{2}=$ perbedaan klinis yang diinginkan 0,5

$Z_{\alpha}=$ tingkat kemaknaan $\left(\alpha=5 \% Z_{\alpha}=1,96\right)$

$Z_{\beta}=$ power penelitian $\left(\beta=20 \% \quad Z_{\beta}=0,84\right)$

$\mathrm{S}=$ standar deviasi $2,4 .^{17}$

Pengambilan subjek menggunakan teknik random blok yang tediri dari Blok $\mathrm{A}$ adalah kelompok perlakuan yang dilakukan masase selama 30 menit dan Blok B adalah kelompok kontrol yang tidak dimasase. ${ }^{18-20}$

Masase pada punggung adalah memberikan stimulasi pada punggung dengan cara melakukan gosokan lembut dengan kedua telapak tangan dan jari pada punggung ibu bersalin setinggi servikal 7 kearah luar menuju sisi tulang rusuk selama 30 menit dengan frekuensi 40 x gosokan/menit, dan dengan tekanan diperkirakan $100 \mathrm{mmH}_{2} \mathrm{O}$ pada ibu bersalin kala I fase laten persalinan normal.

Instrumen yang digunakan adalah kuisioner untuk menilai intensitas nyeri dan human beta endorfin Elisa kit untuk menilai kadar endorfin dalam darah ibu bersalin serta sphygmomanometer untuk mengukur tekanan pijatan ringan.

Pengukuran yang dilakukan adalah intensitas nyeri dan kadar endorfin dalam serum darah ibu bersalin primiparakala I fase laten persalinan normal pada kelompok yang dimasase dan yang tidak dimasase.

Data yang diperoleh diolah secara komputerisasi dan dianalisis dengan uji statistik uji $t$ test independent dan korelasi Spearmen untuk mengetahui pengaruh masase pada punggung terhadap intensitas nyeri ibu bersalin normal melalui peningkatan kadar endorfin. ${ }^{16,21}$
Hasil

Penelitian telah dilakukan terhadap 52 responden yang memenuhi kriteria inklusi yang terdiri dari dua kelompok (kelompok A sebanyak 26 responden dan kelompok $B$ sebanyak 26 responden). Kelompok A merupakan kelompok yang diberikan perlakuan dengan masase selama 30 menit dan kelompok B merupakan responden yang tidak diberikan perlakuan masase.

Tabel 1. Karakteristik Responden Berdasarkan Umur dan Usia Kehamilan

\begin{tabular}{lccc}
\hline Karakteristik & $\begin{array}{c}\text { Perlakuan } \\
(\mathbf{n}=26)\end{array}$ & $\begin{array}{c}\text { Kontrol } \\
(\mathbf{n}=26)\end{array}$ & $\boldsymbol{p}$ \\
\cline { 2 - 3 } & Mean \pm SD & Mean \pm SD & \\
\hline $\begin{array}{l}\text { Umur (tahun) } \\
\text { Usia }\end{array}$ & $25,34 \pm 3,36$ & $24,92 \pm 3,27$ & 0,647 \\
Kehamilan & $38,73 \pm 1,31$ & $38,96 \pm 1,50$ & 0,559 \\
(MG) & & & \\
\hline
\end{tabular}

Dari tabel 1 dapat dilihat bahwa rerata umur responden pada kelompok intervensi dan pada kelompok kontrol hampir sama yaitu berturut - turut $25.34 \pm 3.36$ tahun dan $24.92 \pm 3.27$ tahun, dan secara statistik dapat dinyatakan setara. Rerata usia kehamilan pada kelompok intervensi $38.73 \pm 1.31$ minggu dan kelompok kontrol $38.96 \pm 1.50$ minggu, dan secara statistik dapat dinyatakan setara.

Tabel 2. Perbedaan Rerata Intensitas Nyeri lbu Bersalin Normal Kala I Fase Laten

\begin{tabular}{lccc}
\hline & Rerata & $\begin{array}{c}\text { Standar } \\
\text { Deviasi ( } \pm \text { ) }\end{array}$ & $\boldsymbol{p}$ \\
\hline Kelompok masase & 23.84 & 2.52 & 0.001 \\
Kelompok tidak & 53.46 & 3.90 & \\
masase & & & \\
& & &
\end{tabular}

Tabel 2 menunjukkan intensitas nyeri ibu bersalin normal kala I fase laten pada kelompok yang dimasase lebih rendah dibandingkan dengan kelompok yang tidak dimasase, perbedaan tersebut sebesar 29.62 point. Secara statistik ada perbedaan yang signifikan dengan nilai $p=0.001$, maka dapat dinyatakan ada pengaruh masase pada punggung terhadap intensitas nyeri kala I fase laten persalinan normal. 
Tabel 3. Perbedaan Rerata Kadar Endorfin Ibu Bersalin Normal Kala I Fase Laten

\begin{tabular}{lccc}
\hline & Rerata & $\begin{array}{c}\text { Standar } \\
\text { Deviasi ( } \pm \text { ) }\end{array}$ & $\boldsymbol{p}$ \\
\hline Kelompok masase & 279.26 & 168.26 & 0.001 \\
Kelompok tidak & 136.44 & 45.38 & \\
masase & & & \\
\hline
\end{tabular}

Tabel 3 menunjukkan kadar endorfin ibu bersalin normal kala I fase laten pada kelompok yang dimasase lebih tinggi dibandingkan dengan kelompok yang tidak dimasase, perbedaan tersebut sebesar $142.82 \mathrm{pcg} / \mathrm{ml}$. Secara statistik terdapat perbedaan yang signifikan $p=0,001$, maka dapat dinyatakan ada pengaruh masase pada punggung terhadap kadar endorfin pada ibu bersalin kala I fase laten persalinan normal.

Intensitas Nyer

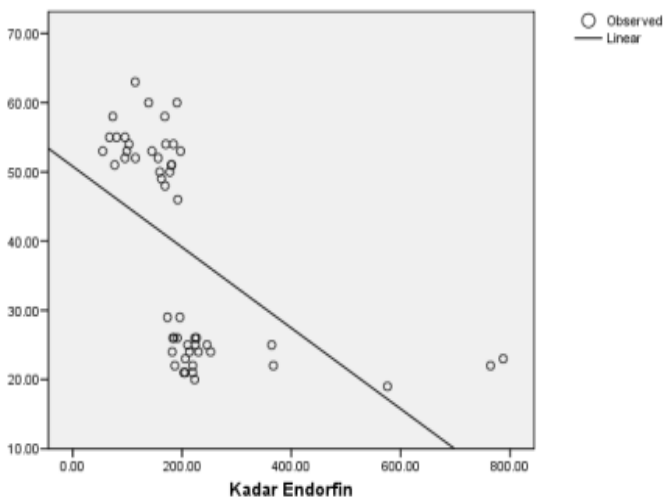

Gambar 1. Korelasi Kadar Endorfin dengan Intensitas Nyeri

Gambar 1 menunjukkan makin tinggi kadar endorfin maka semakin turun intensitas nyeri yang dirasakan oleh ibu bersalin. Secara statistik korelasi ini signifikan dengan $r=0,795$ dan nilai $p=0.001$. Maka dapat dinyatakan ada korelasi antara kadar endorfin dengan intensitas nyeri.

\section{PEMBAHASAN}

Pada penelitian ini diperoleh hasil ada pengaruh masase terhadap intensitas nyeri kala I fase laten persalinan normal melalui peningkatan kadar endorfin.

\section{A. Pengaruh Masase Pada Punggung Terhadap Intensitas Nyeri}

Intensitas nyeri responden pada kelompok yang dimasase lebih rendah dibandingkan dengan kelompok yang tidak dimasase, perbedaan tersebut sebesar 29.62 point. Secara statistik perbedaan tersebut signifikan $p=0.001$, maka dapat dinyatakan ada pengaruh masase pada punggung terhadap intensitas nyeri kala I fase laten persalinan normal.

Pada penelitian ini memberikan hasil bahwa masase pada punggung yang dimulai pada servikal 7 kearah luar menuju sisi tulang rusuk selama 30 menit dapat mengaktivasi serabut saraf berdiameter besar untuk menutup pintu gerbang hantaran nyeri yang dibawa oleh serabut saraf berdiamater kecil sehingga tertutupnya hantaran nyeri ke kortek serebral dan mengakibatkan nyeri berkurang. ${ }^{10}$

Mekanisme pemijatan menggunakan teori pengendalian gerbang informasi nyeri yang bergantung pada keseimbangan aktifitas diserat saraf berdiamater besar dan kecil disepanjang spina columna yang dapat menghambat hantaran nyeri ke otak. $^{11}$

Hasil penelitian ini sejalan dengan penelitian di RSUD Tidar Malang menyebutkan teknik counter pressure yang dilakukan di daerah lumbal dapat memblok reseptor nyeri dari rahim dan servik yang berjalan bersama saraf simpatik memasuki sumsum tulang belakang melalui torakal 10-12 sampai lumbal 1 yang dapat menurunkan intensitas nyeri persalinan kala I fase aktif. Teknik counter pressure lebih efektif menurunkan nyeri dibandingkan teknik abdominal lifting yang dilakukan dengan cara mengusap pada puncak perut ibu bersalin tanpa menekan kearah bawah. $^{14}$

Begitu juga dengan penelitian di Demak menyebutkan ada pengaruh endorphine massage terhadap intensitas nyeri kala I persalinan normal ibu primipara, pada penelitian ini yang dinilai efek masase terhadap intensitas nyeri sedangkan penilaian kadar endorfin tidak dilakukan disamping itu tempat dimanan melakukan masase masase tidak disebutkan. Hasil penelitiannya menyebutkan bahwa nyeri pada saat 
persalinan dapat dikurangi melalui endorphine massage, endorphine massage dapat menghambat hantaran nyeri sehingga dapat menurunkan intensitas nyeri yang dirasakan oleh ibu bersalin kala I fase persalinan normal. ${ }^{13}$

Penelitian di Kanada menyebutkan bahwa masase terapi yang dilakukan pada kala I fase aktif pada ibu bersalin normal primipara menyebutkan dengan melakukan masase selama 5 jam dapat menunda penggunaan analgesik epidural. Responden yang dimasase lebih lambat menggunakan analgesik dengan pembukaan servik satu $\mathrm{cm}$ dibanding yang tidak dimasase oleh terapi pijat, dan intensitas nyeri pada kelompok yang dipijat lebih rendah 20 point dibandingkan yang menggunakan analgesik epidural. $^{22}$

Pada penelitian ini ibu bersalin yang dilakukakan masase pada punggung yang dimulai pada servikal 7 kearah luar menuju sisi tulang rusuk selama 30 menit terjadi aktivasi pada serabut saraf besar sehingga terjadi penutupan pintu gerbang hantaran nyeri yang dapat menghambat transmisi nyeri dimedula spinalis ke otak untuk mempersepsikan nyeri sehingga nyeri tidak begitu terasa.

Secara statistik ada pengaruh masase pada punggung terhadap intensitas nyeri kala I fase laten persalinan normal dengan nilai $p=0.001$. Masase pada punggung merupakan salah satu asuhan kebidanan yang dapat mengurangi rasa nyeri yang dialami ibu saat persalinan.

\section{B. Pengaruh Masase Pada Punggung terhadap Kadar endorfin}

Pada penelitian ini didapatkan kadar endorfin ibu bersalin pada kelompok yang dimasase lebih tinggi dibandingkan dengan kelompok yang tidak dimasase, perbedaan tersebut sebesar $142.82 \mathrm{pcg} / \mathrm{ml}$. Secara statistik terdapat perbedaan yang signifikan $p=0.001$, maka dapat dinyatakan ada pengaruh masase pada punggung terhadap kadar endorfin ibu bersalin kala I fase laten persalinan normal.

Hasil penelitian yang dilakukan di Iran menyebutkan bahwa masase pada kala I fase aktif dapat mempercepat kemajuan persalinan, mengurangi lama persalinan dan penurunan kadar plasma kortisol.
Disamping itu masase dapat meningkakan sekresi opioid endogen (endorfin). Dengan Masase dapat merangsang serabut saraf berdiamter besar dan serat para simpatis di mesencephalon yang dapat mengurangi nyeri dan stres saat persalinan dan dapat mempercepat proses persalinan. ${ }^{12,23}$

Penelitian yang dilakukan di Florida, masase yang dilakukan pada orang dewasa yang sehat sebagai subyek penelitian, menunjukkan tidak terdapat perbedaan yang bermakna kadar $\beta$-endorphin dan $\beta$ lipotropin kelompok yang dimasase dengan yang tidak dimasase. Hal ini disebabkan subyek penelitian adalah orang dewasa yang sehat atau pasien yang tidak mengalami nyeri. Sementara endorfin akan disekresi oleh kelenjer hipofisis pada keadaan nyeri, stres atau cedera jaringan tubuh. ${ }^{17}$

Masase merupakan salah satu metoda yang dapat merangsang analgesik endogen (endorfin). Masase mengganggu transmisi nyeri dengan cara meningkatkan sirkulasi neurotransmitter yang dihasilkan secara alami oleh tubuh pada sinaps neural di jalur sitem saraf pusat. Endorfin berikatan dengan membran prasinaptik, menghambat pelepasan substansi $\mathrm{P}$ yang dapat menghambat transmisi nyeri, sehingga nyeri berkurang. ${ }^{23,24}$

Ketika sentuhan dan nyeri dirangsang bersama, sensasi sentuhan berjalan keotak sementara sistem kontrol desenden merangsang thalamus untuk mensekresi endorfin yang menutup pintu gerbang hantaran nyeri di medulla spinalis. ${ }^{24}$

Pijatan mempunyai efek distraksi yang dapat merangsang reseptor opiat yang berada pada otak dan spinal cord. Sistem saraf pusat mensekresi opiat endogen (endorfin) melalui sistem kontrol desenden yang dapat membuat relaksasi otot. Endorfin mempengaruhi transmisi nyeri yang di interpretasikan oleh pusat pengatur nyeri. ${ }^{10}$

Pemijatan ringan dapat meningkatkan pelepasan oksitosin sebuah hormon yang memfasilitasi persalinan yang dapat mempercepat proses persalinan dan opiat endogen yang dapat mengurangi nyeri persalinan. Masase ringan dilakukan pada seekor kelinci selama 7 hari dengan membelai pada punggung kelinci. Stimulasi sensorik berupa pijatan ringan seperti membelai dengan kecepatan rendah $(\geq 20 \mathrm{~cm} /$ detik $)$ dan frekuensi $40 \mathrm{x}$ 
gosokan/menit, dengan tekanan diperkirakan 100 $\mathrm{mmH20}$. Pijat seperti membelai diuji dan dikonfirmasi dengan aplikasi tekanan serupa untuk mengukur tekanan kecil. ${ }^{15,25}$

Munculnya endorfin dalam tubuh bisa dipicu melalui berbagai kegiatan, seperti pernafasan yang dalam, relaksasi serta mediasi. Mekanisme relaksasi mengurangi nyeri dengan cara mengurangi sensasi dan dengan mengontrol intensitas reaksi terhadap nyeri serta mengurangi ketegangan yang timbul. Sedangkan situasi seperti stres dan nyeri selama persalinan menyebabkan peningkatan kadar endorfin. Tingkatan endorfin berbeda antara satu individu disatu situasi dengan situasi lain., ${ }^{1,10}$

Hasil penelitian ini sejalan dengan pendapat yang dikemukan oleh Sherwood dan Mander bahwa masase yang dilakukan pada punggung selama 30 menit pada ibu bersalin kala I fase laten berpengaruh terhadap peningkatan kadar endorfin. Masase pada ibu bersalin pada kelompok perlakuan merangsang thalamus untuk mensekresi endorfin yang menutup pintu gerbang hantaran nyeri di medulla spinalis. ${ }^{10,26}$

Masase mempunyai efek distraksi yang dapat merangsang reseptor opiat yang berada pada otak dan spinal cord. Sistem saraf pusat mensekresi opiat endogen (endorfin) dalam sistem kontrol desenden. ${ }^{24}$

Pada penelitian ini terdapat perbedaan kadar endorfin pada kelompok yang dimasase sebanyak 19 responden sedangkan pada kelompok yang tidak masase kadar endorfin dibawah nilai normal kadar endorfin ibu bersalin kala I fase laten.

Endorfin yang dihasilkan pada kelompok perlakuan bervariasi, kadar endorfin berbeda antara satu individu disatu situasi dengan situasi lain karena stres dan nyeri selama persalinan menyebabkan perbedaan kadar endorfin tersebut. Hal inilah yang mengakibatkan terjadinya variasi rerata kadar endorfin ibu bersalin kala I fase laten persalinan normal pada kelompok perlakuan dengan kelompok kontrol. Kadar endorfin seseorang dapat juga dipengaruhi oleh faktor lain seperti faktor fisik dan psikologis seseorang, misalnya seks juga merupakan pemicu pelepasan. ${ }^{1,25}$

Setelah dilakukan masase pada punggung ibu bersalin kala I fase laten yang mengalami nyeri saat persalinan terjadi peningkatan kadar endorfin pada kelompok perlakuan sedangkan pada kelompok kontrol tidak terjadi peningkatan kadar endorfin.

Hasil penelitian ini pada kelompok perlakuan yang dimasase selama 30 menit rerata kadar endorfin diatas nilai normal sedangkan pada kelompok kontrol rerata kadar endorfin berada pada nilai normal dan bahkan ada yang dibawah nilai normal kadar endorfin ibu bersalin kala I fase laten.

Secara statistik terdapat perbedaan yang bermakna dengan $p$ value 0.001 , sehingga masase dapat digeneralisasi sebagai asuhan yang baik untuk menstimulasi kadar endorfin yang dapat memberikan rasa nyaman pada saat persalinan.

\section{Korelasi Kadar Endorfin Terhadap Intensitas Nyeri}

Pada penelitian ini didapat makin tinggi kadar endorfin maka semakin turun intensitas nyeri yang dirasakan oleh ibu bersalin. Secara statistik korelasi tersebut signifikan $(p<0.05)$.maka dapat dinyatakan ada korelasi antara kadar endorfin dengan intensitas nyeri. Korelasi antara kadar endorfin dengan intensitas nyeri mempunyai korelasi negatif. Hasil uji statistik $r=$ 0,795 dan nilai $p=0.001$.

Merangsang titik tertentu di sepanjang meridian medulla spinalis, yang ditransmisikan melalui serabut saraf besar ke formatio retikularis, thalamus dan system limbik tubuh akan melepaskan endorfin. Endorfin memiliki peran mengurangi nyeri dan stres, sehingga memberikan kenyamanan pada ibu bersalin. $^{9}$

Masase mengganggu transmisi nyeri dengan cara meningkatkan sirkulasi neurotransmitter yang dihasilkan secara alami oleh tubuh pada sinaps neural di jaras sistem saraf pusat. Endorfin berikatan dengan membran prasinaptik, menghambat pelepasan substansi $\mathrm{P}$ yang dapat menghambat transmisi nyeri, sehingga nyeri berkurang. ${ }^{21}$

Endorfin merupakan neurotransmitter atau neuromodulator yang menghambat pengiriman pesan nyeri, dengan demikian keberadaan endorfin pada sinaps sel saraf menyebabkan penurunan sensasi nyeri. Oleh karena itu seseorang yang memiliki kadar endorfin rendah akan lebih merasakan nyeri dibandingkan dengan yang kadar endorfin tinggi. ${ }^{11}$ 
Selain rangkaian yang menghubungkan nosiseptor perifer dengan struktur SPP yang lebih tingi untuk persepsi nyeri SSP juga mensekresi analgesik endogen penekan nyeri. SSP menekan penyaluran nyeri sewaktu impuls tersebut masuk ke medulla spinalis. Ada dua jalur analgesik desenden yaitu pada substansia grisea periakuaduktus dan stimulasi formatio retikularis di dalam batang otak yang berikatan dengan reseptor opiat di ujung serat nyeri aferen. Pengikatan ini menekan pelepasan substansia $P$ melalui inhibisi prasinaps, sehingga transmisi nyeri ke pusat yeng lebih tinggi dihambat. ${ }^{23}$

Hasil penelitian ini sesuai dengan pendapat yang dikemukan oleh Price dan Wilson masase yang dilakukan pada punggung selama 30 menit akan menghambat transmisi nyeri melalui serabut saraf besar ke formatio retikularis, thalamus dan system limbik tubuh akan melepaskan endorfin. Endorfin berperan sebagai neuromodulator menghambat pengiriman pesan nyeri. Berdasarkan hasil uji korelasi di peroleh $r=0,795$ dan nilai $p<0,005$. Terdapat kekuatan hubungan yang kuat antara kadar endorfin dengan intensitas nyeri kala I persalinan normal.

\section{KESIMPULAN}

Ada pengaruh masase pada punggung terhadap intensits nyeri kala I fase laten persalinan normal. Ada pengaruh masase pada punggung terhadap kadar endorfin ibu bersalin kala I fase laten persalinan normal. Ada pengaruh masase pada punggung terhadap intensits nyeri kala I fase laten persalinan normal melalui peningkatan kadar endorfin.

\section{UCAPAN TERIMA KASIH}

Penulis mengucapkan terima kasih kepada Poltekkes Kemenkes Pekanbaru atas kesempatan yang diberikan untuk melanjutkan pendidikan. Kepada RS Tk. III Dr. Reksodiwiryo Padang dan laboratorium Biomedik Fakultas Kedokteran Universitas Andalas Padang sebagai tempat penelitian atas fasilitas yang telah diberikan.

Terimakasih juga diucapkan kepada DR.dr.H.Masrul,MSc.SpGK dan Bd. Lisma Evareny,SKp.MPH sebagai pembimbing atas masukan dan bimbingan dalam menyelesaikan tesis ini serta semua pihak yang telah membantu dan bekerjasama namun tidak bisa penulis sebutkan satu persatu dalam artikel ini.

\section{DAFTAR PUSTAKA}

1. Cunningham FG. Obstetri Williams, Volume 1. Jakarta: EGC; 2013.

2. Reeder SJ, Martin LL, Koniak-Griffin D. Keperawatan maternitas: kesehatan wanita, bayi \& keluarga. Jakarta: EGC; 2011.

3. Rohani, Saswita R, Marisah. Asuhan kebidanan pada masa persalinan. Jakarta: Salemba Medika; 2011.

4. Bobak IM, Lowdermilk DL, Jensen MG, Perry SE. Buku ajar keperawatam maternitas. Edisi ke-4. Jakarta: EGC; 2004.

5. Departemen Kesehatan Republik Indonesia. Asuhan persalinan normal. Jakarta: Depkes RI; 2008.

6. Walsh D. Evidence - based care for normal labour and birth: a guide for midwife. Francis: Routledge ;2007.

7. Nurasiah A, Rukmawati A, Badriah DL. Asuhan persalinan normal bagi bidan. Bandung: Refika Aditama; 2012.

8. Guyton AC, Hall JE. Fisiologi kedokteran buku ajar. Edisi ke-11. Jakarta: EGC; 2007.

9. Budiarti KD. Hubungan akupresur dengan tingkat nyeri dan lama persalinan kala i pada ibu primipra di Garut (tesis). Jakarta: Universitas Indonesia; 2011.

10. Mander R. Nyeri persalinan. Jakarta: EGC; 2003.

11. Price SA, Wilson LM. Patofisiologi. konsep klinis proses - proses penyakit. Jakarta: EGC; 2006.

12. Hosseini E, Asadi N, Zareei F. Effect of massage therapy on labor progress and plasma levels of cortisol in the active stage of first labor. Iran: Departement of Biology, Science And Research Branch, Islamic Azad University. 2013;15(9):35-8.

13. Azizah IN, Widyawati MN, Anggraini NN. Pengaruh endorphin massage terhadap intensitas nyeri kala i persalinan normal ibu primipara di BPS $S$ dan B Demak (diunduh 23 Maret 2013). Tersedia dari: URL: HYPERLINK http://jurnal.unimus.ac.id

14. Pratiwi DA, Setyowati H,W ijayanti K. Efektifitas teknik abdominal lifting dan counter pressure dalam mengatasi nyeri persalinan fase aktif kala I 
di RSUD Tidar. Program studi ilmu keperawatan

Universitas Muhammadiyah (diunduh 3 Maret 2013). Tersedia dari: URL: HYPERLINK http://journals.mui.ac.ir/index.php/iinmrl/article/dow nload/1869/735.

15. Irene L, Yu LC, Moberg Ku, Wang J, Yu C, Kurosawa M, Agren Grose A, Lekman M and Thomas L. Repeated massage-like stimulation induces long-term effects on nociception: contribution of oxytocinergic mechanisms, European Journal of Neuroscience. 2002 16:330-8.

16. Sastroasmoro S, Ismael S. Dasar-dasar metodologi penelitian klinis. Edisi ke-4. Jakarta: Sagung Seto; 2011.

17. Day JA, Mason RR, Chesrown SE. Effect of massage on serum level of $\beta$-endorphin and $\beta$ lipotropin in healthy adults. Journal of the American Physical Therapy Association and Physical Therapy (diunduh 1 Januari 2014). Tersedia dari: URL: HYPERLINK http://ptjournal.apta.org/

18. Melzack R. The McGill pain questionnaire: pain measurement and assesment. New York: Raven Press; 1988.

19. Fatimah D, Fred N, Zhou Q, Poromaa IS, Akerud $H$. Plasma levels od $\beta$-endorphin during pregnancy and use of labor analgesia. Reproductive Sciences. (diunduh 8 Agustus 2013). Tersedia dari: URL: HYPERLINK http://rsx.sagepub.com/

20. Cameron JR, Skofronick JG, Grant RM. Fisika tubuh manusia. Edisi ke-2. Jakarta: Sagung Seto; 2006.

21. Dahlan MS. Statistik untuk kedokteran dan kesehatan. Edisi ke-5. Jakarta: Salemba Medika; 2008.

22. Janssen $P$, Shroff $F$, Jaspar $P$. Massage therapy and labor outcomes : a randomized conrtolled trial. International Journal of Therapeutic Massage and Bodywork. 2012:5(4):15-20.

23. Rokade BP. Release of endomorphin hormone and its effects on our body and moods: a review. International Conference on Chemical, Biological and Environment Sciences 2011: 436-8.

24. Fraser DM, Cooper AM. Myles midwives. Edisi ke15, New York: United Kingdom. Churchilll Livingstone Oxford; 2009.

25. Mongan MF. Hypno birthing the Mongan method, Jakarta: Bhuana IImu Populer; 2011.

26. Sherwood L. Fisiologi manusia : dari sel ke sistem, Edisi ke-6. Jakarta: EGC; 2011.

27. Farrer H. Keperawatan Maternitas. Edisi ke-2. Jakarta: EGC; 2001.

28. Kamalifard, Shahnazi M, Melli MS, Allahverdizadeh S, Torby S, Ghahvechi. The Efficacy of massage therapy and breathing techniques on pain intensity and physiological respones to labor pain. Journal of Caring Sciences. Journal of caring sciences (diunduh 13 November 2013). Tersedia dari: URL: HYPERLINK http://journals.tbzmed.ac.ir/JCS 